\title{
IMPORT PENETRATION RATE IN VIEW OF A NEW CONCEPT OF MEASURING FOREIGN TRADE
}

The article discusses the issue of import market penetration (IPR). The formula that has been in use so far assumes that the products manufactured and exported by a given country do not contain any foreign value and, likewise, the goods imported by a country do not contain any domestic value. In today's open economy, however, the models taking such assumptions significantly distort the picture of the reality. The new concept on measuring foreign trade based on added value is an attempt at eliminating this limitation. Accordingly, it would be justifiable to modify the formula of the indicator so that it could account for the foreign value in the production and exports, while leaving out the domestic value in imports. The article is an attempt to develop such a formula and apply it to the assessment of the import penetration rate for the EU-15 countries. It was assumed that the inclusion of foreign value in the domestic production would cause the import penetration rate to be higher than in the case of using the old formula. The calculations were conducted with data from the OECD-WTO Database and WIOD Database. The results for the selected years from the period 1995-2011 did not allow to unequivocally confirm the hypothesis in the case of the selected group of countries. They show, however, that the import penetration rate in the EU-15 countries has risen irrespective of the method applied. On the other hand, the value of the modified indicator for agricultural and industrial goods in total was on average lower that the values calculated using the standard method by approximately 6-10 percentage points. The modified IPR was lower than the traditional one for textiles, chemicals, basic metals and fabricated metal products, computer and electronic equipment, transport equipment, but for the other groups the corrected IPR was higher than the traditional one. EU.

Keywords: international trade, import penetration, trade in value added, foreign trade of

JEL classification: F100, F140, F150, F400

DOI: $10.15611 /$ aoe.2017.1.11

\section{INTRODUCTION}

The modern global economy is defined as a system within which entities from different countries form an extensive network of trade, production, capital and technological connections [Reinert, Rajan (ed.) 2009]. Integration processes, gaining in strength since the 1950s, and liberal

\footnotetext{
* Department of International Economic Relations, University of Economics in Katowice
} 
tendencies have led to the gradual elimination of barriers to trade in goods and services, granting them access to the markets of other countries.

A characteristic feature of the modern global economy is the social division of labour, according to which entities based in different countries specialise not only in producing particular goods or services, but also in conducting very specific stages of production using a number of intermediate goods supplied from abroad. A modern good or final service is hardly ever of domestic origin only. They tend to contain some "foreign value" in the form of imported goods or intermediate services (both used directly in their production process and indirectly involved in the production of a given good or service).

In light of these changes, it is worthwhile to determine import penetration levels in the domestic markets of particular countries. For this purpose, the import penetration rate (IPR) is used and traditionally it is calculated as the ratio of imports to domestic demand. Yet this formula seems to be in need of a certain adjustment in the context of the conditions of the modern global economy mentioned earlier. The article attempts the modification of the formula that has so far been used to calculate import penetration, accounting for the new concept of measuring foreign trade, i.e. the concept of using trade in added value. The modified formula is then used to estimate an import penetration rate based on empirical data.

The study introduces a hypothesis that the value of the modified import penetration rate is higher than the rate calculated by the traditional method, because foreign input was accounted for in production and exports. In order to verify this hypothesis, the case of the "old" EU member states (EU-15), which belonged to the EU between 1 January 1995 and 1 May 2004, was analysed. The calculations were made using the TiVA database developed by the WTO and OECD [Measuring]. Due to the availability of data, the estimation was carried out only for the selected years: 1995, 2000, 2005, 2009 and 2011.

\section{THE CONCEPT OF THE MEASURING FOREIGN TRADE IN VALUE ADDED}

The careful examination of the structure of the world trade indicates that nowadays over a half of goods and services traded internationally are intermediary goods. In the years 1995-2011, their share in global trade grew from $58 \%$ to $65 \%$ [Measuring, own calculations]. This caused economists to depart from measuring international trade only based on the end value of produced goods and services. The new concept based on trade in added 
value was created in the 1960s by Leontief, who developed the input-output matrix used for the macro-economic analysis of one country [Leontief, Strout 1963, Leontief 1986]. His idea was taken further at the turn of the $21^{\text {st }}$ century, when it was applied to measure trade in added value [Trade in value-added 2012]. This allowed for the reliable assessment of the actual domestic value in the products exported by a given country. The new concept of measuring foreign trade based on added value has, in recent years, become the subject of numerous research studies [Hummels, Ishii, Yi 1999, Johnson, Noguera 2012, Daudin, Rifflart, Schweisguth 2011, Stehrer 2012, Bems, Johnson, Yi 2011, Stehrer 2013, Foster-McGregor, Stehrer 2013, Kuboniwa 2014]. The literature review also reveals a number of research papers on trade characteristics in particular countries or regions, using the concept of measuring trade based on added value. Papers dealing with this issue include [Koopman, Wang, Wei 2008, Dean, Fung, Wang, 2008, Wang, Powers, Wei 2009, Kelly, La Cava 2013, Nagengast, Stehrer 2014].

The new approach to measuring a given country's imports and exports encourages the analysis of import penetration rates in their markets.

\section{IMPORT PENETRATION RATE - TRADITIONAL PERSPECTIVE}

The import penetration rate indicates what share of domestic demand is satisfied by imported goods. The approach used so far presents it as the following formula [STAN Indicators 2011]:

$$
I P R=\frac{I M}{F D}
$$

where: $I P R$ - import penetration rate,

$I M$ - gross imports of the country,

$F D$ - demand of the country.

Final demand in a given country is defined as the production output less exports, increased with the goods from abroad. ${ }^{1}$ This can be presented as:

$$
F D=P R-E X+I M
$$

where: $P R$ - production, gross output, $E X$ - gross exports of the country.

\footnotetext{
${ }^{1}$ It is assumed that all the imported goods are sold in the domestic market.
} 
The import penetration rate, accordingly, is expressed as:

$$
I P R=\frac{I M}{P R-E X+I M} .
$$

This method has so far been used frequently to measure market penetration in a given country [e.g. Fronczek 2011a, 2011b, 2011c, 2012a, $2012 \mathrm{~b}$ (with reference to the Polish market), Mahajan 2006 (the EU market)]. It is also applied in more complex models studying the impact of imports on domestic economies [see e.g. Kasuya, Okada 2003, Ashournia, Munch, Nguyen 2014, Olper, Curzi, Raimondi 2015].

According to this approach, it is assumed that total production output and exported goods were produced in the same country, i.e. they do not contain any foreign value. It is also assumed that the value of the imported goods is only of foreign origin, i.e. they do not contain any domestic value. In a modern economy, these two assumptions do not hold. As has already been mentioned, production stages are allocated between countries and, as a result, domestic output as well as imported and exported goods contain both domestic and foreign value. Based on the classic formula, it is then difficult to assess the actual import penetration levels in a given domestic market.

\section{IMPORT PENETRATION RATE - ATTEMPT OF MODIFICATION}

According to the new concept of measuring foreign trade (trade in added value), the import penetration rate should be modified. The starting point for the considerations undertaken in this article is the assumption that the import penetration rate for the domestic market should account for foreign value in the domestic final demand of the country under examination (foreign value satisfying the domestic final demand), which can be written as: ${ }^{2}$

$$
I P R_{c o r}=\frac{F V_{f d}}{F D} .
$$

where: $I P R_{\text {cor }}$ - corrected import penetration rate,

$F V_{f d}$ - foreign value in the domestic demand,

$F D$ - domestic demand (as in traditional model).

The new concept accounts for domestic value and foreign value in particular components of domestic demand, which was expressed as:

\footnotetext{
${ }^{2}$ Own elaboration.
} 


$$
F D=F V_{p r}+D V_{p r}-F V_{e x}-D V_{e x}+F V_{i m}+F V_{i m}
$$

where: $F V_{p r}$ - foreign value in the domestic production (value of the imported intermediates used in the domestic production),

$D V_{p r}$ - domestic value in the domestic production,

$F V_{e x}$ - foreign value in the exports,

$D V_{e x}-$ domestic value in the exports,

$F V_{\text {im }}$ - foreign value in the imports, excluding the value of the imported intermediates used in the domestic production (to avoid " double counting"),

$D V_{\text {im }}$ - domestic value in the imports (re-imports).

In order to determine the foreign value in the production output, the article assumes that it is the value of imported intermediate goods used in production in a given country (according to the definition that these are goods used in the production process). ${ }^{3}$ The measure of the domestic value in imports is the value of re-imports (i.e. the reduction of the part of domestic goods that were exported only to be re-imported as original products or components of foreign goods).

The reformulation of the above formula leads to:

$$
F D=F V_{p r}-F V_{e x}+F V_{i m}+D V_{p r}-D V_{e x}+D V_{i m}
$$

where: $F V_{p r}-F V_{e x}+F V_{i m}$ measures the foreign value in the domestic demand,

$D V_{p r}-D V_{e x}+D V_{i m}$ measures the domestic value in the domestic demand.

Accordingly, the import penetration rate can be expressed as follows:

$$
I P R_{c o r}=\frac{F V_{p r}-F V_{e x}+F V_{i m}}{P R-E X+I M}
$$

The same formula can be used to calculate the import penetration rate in particular groups of products, substituting respectively:

$$
I P R_{\text {cor } i}=\frac{F V_{p r i}-F V_{e x i}+F V_{i m i}}{P R_{i}-E X_{i}+I M_{i}}
$$

where: $I P R_{\text {cori }}-$ corrected import penetration rate for group of products $i$,

$F V_{p r i}$ - foreign value in the domestic production in group of products $i$ (value of the imported intermediates used for production of group of products $i$ ),

\footnotetext{
${ }^{3}$ In the corrected version, as in the traditional one, it is assumed that all the imported goods (final and intermediate) are sold in the domestic market.
} 
$F V_{\text {exi }}$ - foreign value in exports in group of products $i$,

$F V_{i m i}$ - foreign value in imports in group of products $i$ (excluding the value of intermediates, classified in group of products $i$, used in the domestic production in group of products $i$ ),

$P R_{i} \quad$ - production of group of products $i$,

$E X_{i} \quad$ - value of exported group of products $i$,

$I M_{i} \quad$ - value of imported group of products $i$.

The next part of the study demonstrates the results of the estimation of import penetration levels in the market using the method presented above.

\section{EMPIRICAL RESULTS - THE EUROPEAN UNION}

\subsection{Notes, principles, possible source of errors of estimation of the corrected import penetration rate}

Empirical research turned out to be complicated as the data needed for analysis was either not collected or not available in the adequate format or degree of aggregation. Hence, in order to conduct the calculations, a number of simplifying assumptions needed to be taken, which caused that the results were affected by errors.

The first of these assumption was that the domestically produced output was sold in total (which is not true as all economies have unsold stock) and the calculations used the data on total production output, distorting the obtained result. A more reliable picture would have been generated if only the products that were actually sold in the market had been taken into account. In the traditional approach, it would have been the value of production sold, while in the modified approach - the foreign value in the sold production. Due to this limitation the results are slightly lower. On the other hand, the error affects both methods, so conclusions can be drawn on the difference between import penetration determined by the classic method with import penetration calculated using the modified approach.

Secondly, it was assumed that the foreign value in production output in a given country was the value of imported intermediate goods used in groups of products and in total production. The estimations of these data were made using the WIOD Database (World Input-Output Database). An additional difficulty is posed by the lack of information on what part of imported intermediate goods is used in the output for export.

Another problem is to determine the domestic value in imported products. It was assumed that this was the value of re-imports, but this is not correct as 
according to the available statistics, re-imports comprise only finished goods that were first exported and then brought back from abroad [Re-exports 2009]. The value of domestic intermediate goods in finished goods imported to a country should also be included. This, alas, is not possible due to the lack of relevant data.

Despite the reservations concerning the weaknesses of the tool, an attempt was made to use it for the evaluation of import market penetration based on the data for the "old" EU member states (EU-15), i.e. the countries belonging to the European Union in the years 1995-2004. ${ }^{4}$

\subsection{Import penetration rate of the market in the old European Union countries - results of estimation for agricultural and industrial goods}

Analysis was conducted for agricultural and industrial goods, with the exclusion of services. The goods were grouped according to the International Standard Industry Classification of All Economic Activities (ISIC rev. 3). ${ }^{5}$

Industrial goods, especially processed ones, had the largest share in the EU-15 foreign trade: about 95\% in exports and $82-90 \%$ in imports (their share in imports decreased slightly over the researched years). The most important products were: chemicals $(10-15 \%$ of the EU foreign trade), machinery and equipment (products from groups 29-33 accounted in total for $25 \%$ of trade) as well as transport equipment (about $15 \%$ of exports and imports). Table 1 presents the complete data.

The results of the estimation presented in Table 2 indicate that irrespectively of the adopted approach, the import penetration rate in the markets of the "old" EU member states increased. In 1995 the value of the corrected import penetration rate for agricultural goods stood at about $17.5 \%$ (traditional IPR - 13.5\%), while for industrial goods in total - 22.2\% (traditional IPR $-28.3 \%$ ), including mining goods $-47.2 \%$ (traditional IPR $45.1 \%$ ) and processed industrial goods $-23.5 \%$ (traditional IPR $-29.4 \%$ ). In 2011, the results were respectively: for agricultural goods $-24.8 \%$ (traditional IPR $-19.6 \%$ ), for industrial goods in total $-26.1 \%$ (traditional IPR $-36.5 \%$ ), including mining goods $-75.6 \%$ (traditional IPR - 75.7\%) and processed industrial goods $-27.9 \%$ (traditional IPR $-37 \%$ ).

\footnotetext{
${ }^{4}$ The same make-up of the EU was adopted for all the years under study.

${ }^{5}$ The ISIC developed by the United Nations in 1948 underwent several modifications: in 1958 (revision 1), in 1968 (revision 2), in 1989 (revision 3), in 2002 (revision 3.1), in 2008 (revision 4). [Industry].
} 
Table 1

The structure of the foreign trade of the EU-15 by ISIC in selected years (in \%).

\begin{tabular}{|c|c|c|c|c|c|c|c|c|c|c|}
\hline \multirow{2}{*}{ ISIC subsections } & \multicolumn{2}{|c|}{1995} & \multicolumn{2}{|c|}{2000} & \multicolumn{2}{|c|}{2005} & \multicolumn{2}{|c|}{2009} & \multicolumn{2}{|c|}{2011} \\
\hline & EX & IM & EX & IM & EX & IM & EX & IM & EX & IM \\
\hline (01-41) Agriculture and industry & 100 & 100 & 100 & 100 & 100 & 100 & 100 & 100 & 100 & 100 \\
\hline $\begin{array}{l}\text { (01-05) Agriculture, hunting, } \\
\text { forestry and fishing }\end{array}$ & 2.7 & 4.0 & 2.2 & 2.8 & 2.0 & 2.5 & 2.4 & 3.4 & 2.3 & 3.3 \\
\hline $\begin{array}{l}\text { (10-41) Mining, Manufacturing } \\
\text { and Utilities }\end{array}$ & 97.3 & 96.0 & 97.8 & 97.2 & 98.0 & 97.5 & 97.6 & 96.6 & 97.7 & 96.7 \\
\hline $\begin{array}{l}\text { (10-14) Mining and } \\
\text { quarrying }\end{array}$ & 1.5 & 5.2 & 1.9 & 9.5 & 1.8 & 9.7 & 1.8 & 9.6 & 1.9 & 11.8 \\
\hline (15-37) Total Manufacturing & 95.2 & 90.1 & 95.4 & 87.1 & 95.1 & 86.7 & 94.1 & 85.0 & \begin{tabular}{|l|}
93.7 \\
\end{tabular} & 82.8 \\
\hline $\begin{array}{l}\text { (15-16) Food products, } \\
\text { beverages and tobacco }\end{array}$ & 8.0 & 8.1 & 6.4 & 6.5 & 6.7 & 6.8 & 8.0 & 7.9 & 7.3 & 7.3 \\
\hline $\begin{array}{l}\text { (17-19) Textiles, textile } \\
\text { products, leather and footwear }\end{array}$ & 6.0 & 6.7 & 5.2 & 6.0 & 4.4 & 5.8 & 3.9 & 5.8 & 3.7 & 5.4 \\
\hline $\begin{array}{l}\text { (20) Wood and products of wood } \\
\text { and cork }\end{array}$ & 1.1 & 1.3 & 1.0 & 1.1 & 1.0 & 1.1 & 0.9 & 0.9 & 0.8 & 0.8 \\
\hline $\begin{array}{l}\text { (21-22) Pulp, paper, paper } \\
\text { products, printing and } \\
\text { publishing }\end{array}$ & 4.7 & 4.4 & 4.4 & 3.9 & 3.9 & 3.3 & 3.4 & 3.1 & 3.2 & 3.0 \\
\hline $\begin{array}{l}\text { (23) Coke, refined } \\
\text { petroleum products and nuclear } \\
\text { fuel }\end{array}$ & 2.0 & 2.8 & 3.2 & 4.0 & 4.2 & 5.5 & 4.4 & 5.7 & 5.4 & 6.7 \\
\hline $\begin{array}{l}\text { (24) Chemicals and chemical } \\
\text { products }\end{array}$ & 12.5 & 10.8 & 12.6 & 9.4 & 13.6 & 10.6 & 15.5 & 12.0 & 14.9 & 11.5 \\
\hline $\begin{array}{l}\text { (25) Rubber and plastics } \\
\text { products }\end{array}$ & 3.3 & 3.4 & 3.1 & 2.9 & 3.3 & 2.9 & 3.2 & 2.9 & 3.3 & 2.8 \\
\hline $\begin{array}{l}\text { (26) Mostly non-metallic } \\
\text { mineral products }\end{array}$ & 2.1 & 1.6 & 1.8 & 1.3 & 1.7 & 1.3 & 1.6 & 1.3 & 1.5 & 1.2 \\
\hline $\begin{array}{l}\text { (27-28) Basic metals and } \\
\text { fabricated metal products }\end{array}$ & 9.8 & 9.8 & 8.5 & 8.3 & 9.9 & 9.3 & 9.6 & 8.5 & 11.7 & 9.9 \\
\hline $\begin{array}{l}\text { (29) Machinery and equipment, } \\
\text { nec. }\end{array}$ & 12.6 & 8.5 & 11.3 & 8.0 & 11.6 & 7.4 & 12.5 & 7.2 & 12.2 & 6.9 \\
\hline $\begin{array}{l}\text { (30-33) Computer, } \\
\text { electronic and optic }\end{array}$ & 14.2 & 15.9 & 17.6 & 17.6 & 14.0 & 14.0 & 11.9 & 12.4 & 10.9 & 11.0 \\
\hline $\begin{array}{l}\text { (34-35) Transport } \\
\text { equipment }\end{array}$ & 16.0 & 13.9 & 17.7 & 15.3 & 18.3 & 15.7 & 16.1 & 13.4 & 17.2 & 12.9 \\
\hline $\begin{array}{l}\text { (36-37) Manufacturing nec., } \\
\text { recycling }\end{array}$ & 2.8 & 2.7 & 2.7 & 2.9 & 2.5 & 3.1 & 3.1 & 4.0 & 2.2 & 3.6 \\
\hline $\begin{array}{l}\text { (40-41) Electricity, gas and } \\
\text { water supply }\end{array}$ & 0.6 & 0.7 & 0.5 & 0.6 & 1.1 & 1.2 & 1.8 & 2.0 & 2.1 & 2.1 \\
\hline
\end{tabular}

Source: Measuring Trade In Value Added: An OECD-WTO joint initiative, http://www.oecd. org/sti/ind/measuringtradeinvalue-addedanoecd-wtojointinitiative.htm (06-06-2015), own elaboration. 
Table 2

Import penetration rate of the market of the EU-15 in selected years

\begin{tabular}{|c|c|c|c|c|c|c|c|c|c|c|}
\hline \multirow{2}{*}{ ISIC subsections } & \multicolumn{2}{|c|}{1995} & \multicolumn{2}{|c|}{2000} & \multicolumn{2}{|c|}{2005} & \multicolumn{2}{|c|}{2009} & \multicolumn{2}{|c|}{2011} \\
\hline & IPR & \begin{tabular}{|l|} 
IPRcor \\
\end{tabular} & IPR & IPRcor & IPR & IPRcor & IPR & IPRcor & IPR & IPRcor \\
\hline $\begin{array}{l}\text { (01-41) Agriculture and } \\
\text { industry }\end{array}$ & 27.4 & 21.2 & 32.6 & 24.1 & 33.1 & 24.3 & 32.8 & 24.6 & 35.7 & 25.2 \\
\hline $\begin{array}{l}\text { (01-05) Agriculture, } \\
\text { hunting, forestry and } \\
\text { fishing }\end{array}$ & 13.5 & 17.5 & 14.1 & 18.5 & 14.3 & 19.3 & 17.8 & 22.7 & 19.6 & 24.8 \\
\hline $\begin{array}{l}\text { (10-41) Mining, Manu- } \\
\text { facturing and Utilities }\end{array}$ & 28.3 & 22.2 & 33.5 & 25.1 & 33.9 & 25.1 & 33.5 & 25.5 & 36.5 & 26.1 \\
\hline $\begin{array}{l}\text { (10-14) Mining and } \\
\text { quarrying }\end{array}$ & 45.1 & 47.2 & 67.0 & 67.9 & 67.6 & 68.5 & 69.1 & 69.6 & 75.7 & 75.6 \\
\hline $\begin{array}{l}\text { (15-37) Total } \\
\text { Manufacturing }\end{array}$ & 29.4 & 23.5 & 33.9 & 26.3 & 34.6 & 27.0 & 34.6 & 27.8 & 37.0 & 27.9 \\
\hline $\begin{array}{l}\text { (15-16) Food roducts, } \\
\text { beverages and tobacco }\end{array}$ & 15.3 & 19.6 & 16.9 & 21.8 & 18.2 & 22.9 & 19.6 & 24.2 & 21.6 & 26.2 \\
\hline $\begin{array}{l}(17-19) \text { Textiles, textile } \\
\text { products, leather and } \\
\text { footwear }\end{array}$ & 32.0 & 31.0 & 39.2 & 36.5 & 45.7 & 42.3 & 52.1 & 48.8 & 55.3 & 50.2 \\
\hline $\begin{array}{l}\text { (20) Wood and products } \\
\text { of wood and cork }\end{array}$ & 17.8 & 20.6 & 19.0 & 22.9 & 19.8 & 23.4 & 19.1 & 22.5 & 19.8 & 23.6 \\
\hline $\begin{array}{l}\text { (21-22) Pulp, paper, } \\
\text { paper products, printing } \\
\text { and publishing }\end{array}$ & 16.3 & 18.6 & 17.4 & 20.7 & 17.4 & 21.1 & 16.6 & 21.0 & 19.7 & 24.4 \\
\hline $\begin{array}{l}\text { (23) Coke, refined } \\
\text { petroleum products and } \\
\text { nuclear fuel }\end{array}$ & 24.7 & 49.2 & 29.7 & 62.6 & 33.4 & 67.6 & 36.2 & 73.1 & 36.4 & 68.3 \\
\hline $\begin{array}{l}\text { (24) Chemicals and } \\
\text { chemical products }\end{array}$ & 34.0 & 31.4 & 36.9 & 32.8 & 40.9 & 36.0 & 45.1 & 38.7 & 47.2 & 39.0 \\
\hline $\begin{array}{l}\text { (25) Rubber and plastics } \\
\text { products }\end{array}$ & 25.5 & 34.0 & 26.8 & 35.7 & 28.2 & 36.3 & 30.5 & 38.7 & 33.0 & 40.4 \\
\hline $\begin{array}{l}\text { (26)Mostly non-metallic } \\
\text { mineral products }\end{array}$ & 12.8 & 17.4 & 13.9 & 19.2 & 13.5 & 19.0 & 14.6 & 19.6 & 16.9 & 22.3 \\
\hline $\begin{array}{l}\text { (27-28) Basic metals and } \\
\text { fabricated metal products }\end{array}$ & 23.6 & 22.8 & 25.4 & 24.5 & 27.1 & 25.6 & 27.3 & 26.3 & 32.0 & 28.5 \\
\hline $\begin{array}{l}\text { (29) Machinery and } \\
\text { equipment, nec. }\end{array}$ & 31.2 & 32.6 & 35.3 & 36.6 & 34.1 & 35.1 & 36.0 & 35.5 & 36.9 & 37.0 \\
\hline $\begin{array}{l}\text { (30-33) Computer, electro- } \\
\text { nic and optical equipment }\end{array}$ & 43.9 & 39.4 & 51.1 & 42.7 & 50.6 & 44.4 & 47.4 & 44.5 & 48.8 & 45.7 \\
\hline $\begin{array}{l}\text { (34-35) Transport } \\
\text { equipment }\end{array}$ & 40.1 & 37.0 & 43.2 & 37.8 & 44.2 & 38.0 & 42.0 & 36.8 & 43.8 & 37.2 \\
\hline $\begin{array}{l}\text { (36-37) Manufacturing } \\
\text { nec. recycling }\end{array}$ & 23.3 & 30.2 & 28.6 & 35.3 & 30.6 & 37.6 & 38.0 & 42.2 & 38.6 & 44.7 \\
\hline $\begin{array}{l}\text { (40-41) Electricity, gas } \\
\text { and water supply }\end{array}$ & 2.7 & 11.4 & 2.9 & 14.0 & 4.7 & 18.5 & 6.1 & 19.3 & 7.7 & 22.4 \\
\hline
\end{tabular}

$I P R$ - traditional import penetration rate; $I P R_{c o r}$ - corrected import penetration rate.

Source: Measuring Trade In Value Added: An OECD-WTO joint initiative, $\mathrm{http} / / /$ www.oecd.org/sti/ind/measuringtradeinvalue-addedanoecd-wtojointinitiative.htm (0606-2015); WIOD Database, http://www.wiod.org/new site/data.htm (09-01-2016), own calculations and estimations. 
The modified indicator had the highest value for mining products. This implies that in the period 1995-2011, imports satisfied $47-76 \%$ of the EU-15 demand for these products. But it had no significant influence on the total import penetration rate because the share of these products in the EU-15's imports did not exceed $12 \%$. In the case of chemicals, machinery, computers and transport equipment, which constituted a decisive majority of foreign trade, the corrected IPR was equal $32-46 \%$. This implies that $32-46 \%$ of the Union's demand for these products was satisfied by imported goods (the results obtained using the traditional approach ranged from 34\% to 56\%). The modified IPR seems to suggest the higher level of the import penetration for most kinds of goods than the traditional IPR (traditional IPR was lower by approximately 4-37 percentage points). The exceptions were: chemicals (subsection 25), basic metals and fabricated metal products (subsection 2728), computers electronic and optical equipment products (subsection 30-33) and transport equipment (subsection 34-35). In this case the corrected IPR was lower than the traditional one by approximately 1-8 percentage points.

In the researched period, the following EU markets had the lowest market penetration rates: non-metallic mineral products, basic metals and fabricated metal products and, the already mentioned, agricultural products (the traditional IPR ranged from $13 \%$ to $32 \%$, while the corrected IPR - from $17.5 \%$ to $29 \%){ }^{6}$

\section{CONCLUSION}

In the face of progressing liberalisation in foreign trade, integration processes and the developing specialisation of particular countries in different production stages, a new approach to measuring domestic exports and imports is needed. The concept of measuring foreign trade in added value is undoubtedly more suited to describe the modern economy than the method, in general use so far, based on the end value of goods. The adoption of the new approach creates the need to modify other indicators related to foreign trade. One of such indicators is the import penetration rate, showing what share of domestic demand is satisfied by imported goods. The modified formula of the indicator, proposed in Section 3, is based on the new concept. Unfortunately, as has already been indicated, the results yielded by the

\footnotetext{
${ }^{6}$ The following groups were omitted: ISIC 40 and 41 , where the traditional IPR did not exceed $8 \%$ and the corrected IPR $-23 \%$. The goods classified in these groups, water supply, waste water management, sewage management, etc. are by nature difficult to be transported over longer distances.
} 
formula are affected by errors that are mainly caused by the lack or imprecision of relevant empirical data. The author, however, decided that it was worth making an attempt to run calculations based on the selected group of countries.

The results of the estimation presented in the article cause that the testing of the hypothesis formulated in the introduction, which assumed the value of the corrected import penetration rate would be higher than the rate calculated with the method used so far, is equivocal. In the selected example of the EU15 countries, this value turned out to be lower than the value calculated by the traditional method, which indicates that, in reality, imported agricultural and industrial goods covered less domestic demand in the EU-15 than might be inferred from the method used so far. However detailed analysis shows a different situation. The groups of products where the corrected IPR was lower than traditional one were: textiles, chemicals, basic metals and fabricated metal products, computer and electronic equipment, and transport equipment, which indicates that the real import penetration of this market was lower than that calculated by the conventional method. In the case of other groups of products, the modified IPR was higher than the traditional one.

It should be underlined that the considerations presented in this article do not exhaust the issue, and that the proposed formula requires elaboration and empirical analysis in order to make any binding conclusions. The discussion in the article offers only a contribution to further research.

\section{REFERENCES}

Ashournia, D., Munch, J. R., Nguyen, D., The Impact of Chinese Import Penetration on Danish Firms and Workers, Institute for the Study of Labor (IZA), IZA Discussion Papers no. 8166, http://ftp.iza.org/dp8166.pdf (30.09.2015), 2014.

Bems, R., Johnson, R. C., Yi, K.-M., Vertical Linkages and the Collapse of Global Trade, “American Economic Review", Vol. 101 (3), 2011. http://www.aeaweb.org/ articles.php?doi=10.1257/aer.101.3.308 (01.10.2015)

Daudin, G., Rifflart, Ch., Schweisguth, D., Who Produces for Whom in the World Economy?, "Canadian Journal of Economics", No 4, pp. 1403-1437, http://economics.ca/cgi/xms? $\mathrm{jab}=\mathrm{v} 44 \mathrm{n} 4 / \mathrm{CJEv} 44 \mathrm{n} 4 \mathrm{p} 1403 . p d f(07-09-2015), 2011$.

Dean, J., Fung, K. C., Wang, Z., How Vertically Specialized is Chinese Trade?, Bank of Finland, Institute for Economies in Transition, OFIT Discussion Papers, No 31, http://www.suomenpankki.fi/bofit_en/tutkimus/tutkimusjulkaisut/dp/Documents/dp3108. pdf (07-09-2015), 2008.

Foster-McGregor, N., Stehrer, R., Value Added Content of Trade: A Comprehensive Approach, "Economics Letters", Vol. 120, http://www.sciencedirect.com/science/ article/pii/S0165176513002292 (25.09.2015), 2013. 
Fronczek, M., Penetracja importowa polskiego rynku przez towary pochodzace z Chin [The Import Penetration Rate of Polish Market by Commodities from China], „Studia Ekonomiczne", No. 90, Wydawnictwo Uniwersytetu Ekonomicznego, Katowice, pp. 57-67, 2011a.

Fronczek, M., Penetracja importowa polskiego rynku przez towary pochodzace z krajów Europy Środkowo-Wschodniej [Import Penetration Rate of Polish Market by Commodities from Central European Countries], „Studia Ekonomiczne”, No 85, Wydawnictwo Uniwersytetu Ekonomicznego, Katowice, pp. 7-16, $2011 \mathrm{~b}$.

Fronczek, M., Trends in Polish Foreign Trade and the Import Penetration Rate of the Polish Market in Years 1995-2008, "Finanse, Rynki Finansowe, Ubezpieczenia", No 43; Uniwersytet Szczeciński, Szczecin, pp. 43-53, 2011 c.

Fronczek, M., Penetracja importowa polskiego rynku jako przykład procesów globalizacyjnych [Import Penetration Rate of the Polish Market as an Example of the Globalisation Proces], „Prace i Materiały Instytutu Handlu Zagranicznego”, No. 31, Wydawnictwo Uniwersytetu Gdańskiego, Gdańsk, pp. 755-767, 2012a.

Fronczek, M., Penetracja importowa polskiego rynku przez towary pochodzace z krajów Unii Europejskiej [The import penetration of the Polish market by commodities imported from the European Union], „Studia Ekonomiczne”, No 123, Wydawnictwo Uniwersytetu Ekonomicznego, Katowice, pp. 105-117, 2012b.

Hummels, D., Ishii, J., Yi, K.-M., The Nature and Growth of Vertical Specialization in World Trade, Staff Reports Federal Reserve Bank of New York, No 72, http://www.newyorkfed.org/research/staff_reports/sr72.html (17-09-2015), 1999.

Industry classification, UN Statistics Division, http://www.investmentmap.org/ industry_classification.aspx (07-09-2015).

Johnson, R. C., Noguera, G., Accounting for Intermediates: Production Sharing and Trade in Value-added, "Journal of International Economics", Vol. 86, Issue 2 pp. 224-236, http://www.sciencedirect.com/science/article/pii/S002219961100122X (07-09-2015), 2012.

Kasuya, M., Okada, T., The Effects of Technology Changes on the Sectoral Trade Patterns and the Import Penetration Ratio, Bank of Japan, Research and Statistics Department, Working Paper Series, No. 03-4, http://www.boj.or.jp/en/research/wps_rev/wps_2003/ data/cwp03e04.pdf (01.10.2015), 2003.

Kelly, G., La Cava, G., Value-added Trade and the Australian Economy, Reserve Bank of Australia, RBA Bulletin, March, http://www.rba.gov.au/publications/bulletin/ 2013/mar/pdf/bu-0313-4.pdf (25.09.2015), 2013.

Koopman, R., Wang, Z., Wei, S.-J., How Much of Chinese Exports is Really Made in China? Assessing Domestic Value-added When Processing Trade is Pervasive, Working Paper, 14109, National Bureau of Economic Research, Cambridge, June, http://www.nber.org/papers/w14109 (07-09-2015), 2008.

Kuboniwa, M., Trade in Value Added Revisited: A Comment on R. Johnson and G. Noguera, Accounting for Intermediates: Production Sharing and Trade in Value Added, Institute of Economic Research, Hitotsubashi University, Discussion Paper Series, No. 598, http://hermes-ir.lib.hit-u.ac.jp/rs/bitstream/10086/26056/1/DP598.pdf (01.10.2015), 2014.

Leontief, W., Input-Output Economics, Oxford University Press (second edition), https://books.google.pl/ (08-09-2015), 1986. 
Leontief, W., Strout, A., Multiregional Input-Output Analysis, (in:) Barna, T. (ed.), Structural Interdependence and Economic Development, pp. 119-150. St-Martin's Press, New York, http://www.jstor.org/stable/139580 (08-09-2015), 1963.

Mahajan, S., Import Penetration of Goods and Services 1992-2004, "Economic Trends", No. 636, http://www.ons.gov.uk/ons/search/index.html?newquery=import+penetration+of + goods + and+services (25.09.2015), 2006.

Measuring Trade in Value Added: An OECD-WTO joint initiative, http://www.oecd. org/sti/ind/measuringtradeinvalue-addedanoecd-wtojointinitiative.htm (06-06-2015).

Nagengast, A. J., Stehrer, R., Collateral Imbalances in Intra-European Trade? Accounting for the Difference between Gross and Value Added Trade Balances, European Central Bank, Working Paper Series, No. 1695, http://www.ecb.europa.eu/pub/pdf/scpwps/ ecbwp1695.pdf (01.10.2015), 2014.

Olper, A., Curzi, D., Raimondi, V., Import Penetration, Intermediate Inputs and Firms' Productivity in the EU Food Industry, Agricultural and Applied Economics Association Annual Meeting, January 3-5, Boston, Massachusetts, No. 189691, http://purl.umn.edu/189691 (30.09.2015), 2015.

Re-exports and re-imports in UN Comtrade. $2^{\text {nd }}$ Meeting of the Working Party on International Trade in Goods and Services Statistics, 2009, OECD, Paris, www.oecd.org/std/its/44196683.ppt (07-09-2015).

Reinert, K. A., Rajan, R. S. (eds.), The Princeton Encyclopedia of the World Economy. Princeton University Press, Princeton, https://books.google.pl/ (08-09-2015), 2009.

STAN Indicators - Collection of Calculation Formula, 2011, OECD 06 April 2011 www.oecd.org/sti/ind/47447210.pdf(07-09-2015)

Stehrer, R., Trade in Value Added and the Valued Added in Trade, The Vienna Institute for International Economic Studies, Working Papers, No. 81, , http://wiiw.ac.at/trade-invalue-added-and-the-valued-added-in-trade-p-2620.html (01.10.2015), 2012.

Stehrer, R., Accounting Relations in Bilateral Value Added Trade, The Vienna Institute for International Economic Studies, Working Papers, No. 101, , http://wiiw.ac.at/accountingrelations-in-bilateral-value-added-trade-p-3021.html, 2013.

Trade in Value-added: Concepts, Methodologies and Challenges (joint OECD-WTO note), www.oecd.org/sti/ind/49894138.pdf(07-09-2015), 2012.

Wang, Z., Powers, W., Wei, S.-J., Value Chains in East Asian Production Networks: An International Input-output Model Based Analysis, EcoMod2009, No 21500091, http://www.ecomod.net/sites/default/files/document-conference/ecomod2009/903.pdf(0709-2015), 2009.

WIOD Database, http://www.wiod.org/new_site/data.htm (09-01-2016). 